\title{
Belgeo
}

Revue belge de géographie

\section{"I do not want to poach pupils from other schools" \\ - German primary schools and their role in educational choice processes}

"Ich will ja keine Schüler von anderen Schulen abwerben". Deutsche

Grundschulen und ihre Rolle im elterlichen Schulwahlprozess

Isabel Ramos Lobato

\section{(2) OpenEdition}

\section{Journals}

Electronic version

URL: http://journals.openedition.org/belgeo/19131

DOI: 10.4000/belgeo.19131

ISSN: 2294-9135

\section{Publisher:}

National Committee of Geography of Belgium, Société Royale Belge de Géographie

\section{Electronic reference}

Isabel Ramos Lobato, "I do not want to poach pupils from other schools" - German primary schools and their role in educational choice processes », Belgeo [Online], 2-3 | 2017, Online since 31 December 2016, connection on 01 May 2019. URL : http://journals.openedition.org/belgeo/19131 ; DOI :

10.4000/belgeo.19131

This text was automatically generated on 1 May 2019.

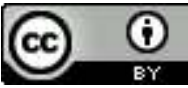

Belgeo est mis à disposition selon les termes de la licence Creative Commons Attribution 4.0 International. 


\title{
"I do not want to poach pupils from other schools" - German primary schools and their role in educational choice processes
}

\author{
"Ich will ja keine Schüler von anderen Schulen abwerben". Deutsche \\ Grundschulen und ihre Rolle im elterlichen Schulwahlprozess
}

Isabel Ramos Lobato

\section{Introduction}

1 Within the German education system, primary schools ${ }^{1}$ are the only "comprehensive" school type. Only in primary schools are all children within one age group taught collectively. Moreover, primary schools have a very local character due to the existence of fixed catchment areas, which should enable efficient planning but also guarantee short distances between homes and school - the so called "short legs, short distances" concept (van Ackeren, 2006). The spatial proximity between home and school should enable children to experience their school and extracurricular life as a unit in which they can move independently. However, the perception of this ideal of the "school next door open for everyone" is changing. Especially among highly qualified parents, there seems to be an increasing lobby for free primary school choice. Research studies illustrate that currently, middle-class parents in particular strategically select primary schools for their children - even though this implies (illegally) circumventing the catchment area (Weishaupt et al., 2012; Riedel et al., 2010; Noreisch, 2007a, 2007b).

In addition to the changing parental perspective on primary school choice, there have also been changes on a policy level. In the federal state of North-Rhine Westphalia (NRW), where this study took place, school catchment areas were abolished in 2008 - in contrast to most federal states in Germany. On the one hand, free primary school choice was 
advertised as a tool to give families in disadvantaged areas the chance to access other and possibly "better" schools than those in their immediate living environment. On the other hand, it was supposed to encourage "responsible competition" (Landtag NordrheinWestfalen, 2006) among primary schools in hopes that it would lead to quality improvements in education. However, early quantitative research studies have shown that at least in some neighbourhoods, school choice has consequently become more socially selective since privileged parents use this freedom more often than disadvantaged families do (Groos, 2015 for the city of Mülheim an der Ruhr).

The aim of this paper is thus to shed light on the changing role of German primary schools in school choice processes. In contrast to the many papers that focus on parents' strategies to ensure access to the "right" schools for their children (Butler \& Hamnett, 2007; Rangvid, 2007; Reay et al., 2011; Hollingworth \& Williams, 2010), this paper rather illustrates the mutual process between parents' increasing demand and educational preferences on the one hand and schools' responses on the other.

\section{Theory}

\section{Parents' strategies for education}

4 Middle-class parents' school choice strategies have been widely reported in the literature. Educational achievement at school plays a crucial role in gaining access to university and good jobs and is crucial in "maintaining and legitimising class differences" (Boterman, 2013,1132 ). Thus, access to high-quality education has become one of the main priorities of middle-class families - not only to ensure upwards social mobility but also to reproduce their existing class position (Butler \& Hamnett, 2007; Boterman, 2013).

-class families' search for the "right" school is increasingly driven by preferences for the schools' composition (Boterman, 2013; Byrne, 2006; Vowden, 2012). Parents are concerned about "the exposure [...] to children from class or racial groups who may be seen to exert a detrimental effect on their own performance" (Butler \& Hamnett, 2007, p. 1165). In that vein, research illustrates the complicated ways in which class is mediated by ethnicity/race (Byrne, 2006, 2009). By associating ethnic differences with material disadvantage and "whiteness with social and economic privilege" (Hollingworth \& Williams, 2010, p. 55), middle-class parents' concerns are mainly related to both the socioeconomic and ethnic composition of schools. In addition to the role of schools' composition in parental choice, in their study on Black middle-class parents, Vincent et al . (2012) illustrate that the intersection of parents' own social and ethnic background shapes their educational strategies.

6 To gain access to the "right" schools, parents pursue different strategies, such as moving into the vicinity of a desired school, (illegally) circumventing catchment areas, "colonising" local schools in diverse urban neighbourhoods or going private (Rangvid, 2007; Reay et al., 2011; Raveaud \& van Zanten 2007; Vowden, 2012; Noreisch, 2007a; Butler \& Robson, 2003). Moreover, parents' educational strategies are influenced by (local) social networks and informal information; they strongly rely on professional networks and institutional advice (Ball \& Vincent, 1998; Holloway, 1998; Byrne, 2006; van Zanten, 2013; Noreisch, 2007b). 


\section{Educational organisations and school choice}

7 Some research studies have also focused on schools' agency and their role in choice processes. The strong pressure to become more effective leads to increased competition among schools, especially in countries such as the UK, where schools are evaluated and ranked in national league tables ${ }^{2}$. Head teachers thus find themselves in a situation where their educational values collide with the need to succeed in the market (Jennings, 2010). Consequently, by attracting the most advantageous students and avoiding the more demanding ones, schools try to achieve good test scores and to increase their reputation, which is strongly linked to pupil intake (Ball, 1994; Ball et al., 1995; Gillborn \& Youdell, 2000; West \& Hind, 2003; Herbert, 2000; van Zanten, 2005).

8 To select their desired clientele, schools draw on different strategies, such as counselling out "problem students", channelling educational paths through alliances with other schools or interviewing parents and their children to assess their desirability (Jennings, 2010; Macguire et al., 1999; West et al., 2003). Moreover, teachers and head teachers often play a decisive role in influencing parental school choice. Depending on parents' social position, teachers and head teachers give inside information, recommend or advise against specific schools and attempt to send signals to families what types of students might fit into the school (van Zanten, 2013; Jennings, 2010). For Berlin, Noreisch (2007a) shows that head teachers often act as gatekeepers and are particularly receptive to active parents since they realise the benefits that these parents can bring to their schools. For Paris, Van Zanten (2013) even points to institutional channelling built by cooperation between primary and secondary school teachers to create "lock-in-systems" (ibid., p. 94).

The majority of research studies on schools' responses to choice processes focus on their strategic behaviour of responding to accountability systems by "gaming the system". According to Jennings (2010), the extent of the adoption of these strategies is strongly linked to head teachers' sensemaking of accountability and the interorganisational networks in which they are embedded, and it is conditioned by their own professional biographies and values. Thus, schools respond in varied ways "that are not simply a function of their short-term incentives" (ibid., p. 229). Moreover, schools are not affected by other schools in the same way; a school's reputation and the competition in the local area determine the surrounding institutional environment's influence on the school (van Zanten, 2005).

\section{Data and methodology}

\section{The study and its interview partners}

10 This paper is based on a research project ${ }^{3}$ examining the impact of middle-class families' influx and their social networks in inner-city neighbourhoods in the city of Düsseldorf, the capital of NRW. The project sought to provide further evidence on the role of educational organisations in promoting or preventing intergroup contacts.

11 The paper draws on 32 expert interviews with head teachers of primary schools and staff of nurseries as well as in-depth semi-structured interviews with parents -29 mothers and four fathers from predominately professional middle class families ${ }^{4}$. Contacts were established through primary schools, nurseries, visits to playgrounds, local contact 
persons, associations and initiatives. The parent sample was ethnically mixed. However, in contrast to studies illustrating the intersection of class and ethnicity/race in shaping parents' educational strategies (Vincent et al., 2012; Rollock et al., 2012), the parents' ethnic background did not appear to be an explanatory variable for their school choice strategies. This might be a result of our specific sample: our interviewees mainly came from other European countries. A research study on discrimination in Germany illustrates that this migrant group is significantly less discriminated against than people with a Turkish, Arabic or African background (Antidiskriminierungsstelle des Bundes, 2015). Thus, it can be assumed that for the latter groups, working "to defend their children and themselves from racism, stereotyping and seemingly entrenched low expectations" (Vincent et al., 2012, p. 273) - similar to the highly stigmatised Black Caribbean parents studied in the research project by Vincent and colleagues - is far more relevant and thus affects their educational strategies to a greater extent than is the case for our interviewees.

\section{The case study neighbourhoods}

The study took place in two urban neighbourhoods in the city of Düsseldorf. Both neighbourhoods - here called Northville and Highfields - offered an interesting contrast of localities. They are very centrally located and within walking distance to one another. Highfields has approximately 30,000 inhabitants on approximately $4 \mathrm{~km}^{2}$; with 21,000 inhabitants and almost $3 \mathrm{~km}^{2}$, Northville is slightly smaller. Both neighbourhoods are former working class areas, and both were part of an urban regeneration programme that was conducted between 1999 and 2008 and focused on disadvantaged urban neighbourhoods highly affected by structural and socio-economic change. However, whereas Northville experienced a very quick gentrification process with a rapid increase in rent and housing prices, Highfields is (still) a more diverse area, characterised by lower rent, a higher share of people depending on social security benefits and a larger migrant population (mainly with Turkish and Moroccan backgrounds).

13 In each neighbourhood, or at least within the vicinity, there are four primary schools. Similar to the different socio-economic structures of the populations, primary schools in Highfields are predominantly attended by children with a migration background (mostly Turkish or Moroccan) and have a comparatively high share of children receiving social security benefits. In Northville, with one exception, the primary schools' intake is predominantly middle-class children, and distinctively fewer children have a migration background.

The abolishment of school catchment areas in NRW was subject of a controversial public debate about educational inequality and segregation. Despite the implementation of free primary school choice, the targeted selection or recruitment of pupils is still a sensitive topic among teachers and head teachers - possibly due to the primary schools' comprehensive mission. Therefore, anonymity is preserved for the neighbourhoods, head teachers and schools.

\section{The German school system}

15 In Germany, the federal states are responsible for education, which leads to several differences, such as years of primary school and the transition from primary to secondary 
schools. After four years (in some federal states, after six years) of common schooling in primary schools, pupils are distributed into different educational tracks depending on their level of achievement. The Gymnasium is the highest track, which prepares students for tertiary education ${ }^{5}$. The transition from primary to secondary education is based on the recommendation of the primary school. The subsequent decision is made by the parents (e.g., NRW) or by the school, or it is dependent on the fulfilment of specific performance criteria (e.g., Bavaria). The fact that changes from lower to higher tracks are still an exception elucidates the importance and implications of the transition from primary to secondary school and might explain the concerns many parents feel when choosing a primary school for their children.

\section{Primary school choice: Parents' perspectives and schools' reactions}

\section{Parental school choice}

16 In both neighbourhoods, our interviews reveal similarities in terms of values, perspectives and preferences for schooling. The parents seem to be skilled and alert choosers deploying all the classic tactics for operating successfully within the educational market (Vincent \& Ball, 2001). Moreover, parents in both neighbourhoods appreciate the presence of social and ethnic "others". However, whereas parents in Northville downplay the role of the school's composition and rather emphasise the important role of spatial proximity in their choices, parents in Highfields are far more sceptical. Their concerns mainly seem to be related to the ethnic composition of the local schools - or even, more precisely, to the other children's proficiency in German. Although they would also prefer to send their children to a primary school next door, parents in Highfields send their children to schools outside the neighbourhood to avoid an environment that pays particular attention to other children's needs (especially in terms of language) and thus slows down the pace for all children.

"The nearest school was the one in Hemlock Street. We went there to have a look, and of course, we were welcomed with open arms. But we realised that this school is focused on the promotion of the German language. Then we said, thank god our child is not highly talented, but he definitively has some talents which need to be promoted. And we do not want to send him to a school where the promotion of the German language is the main goal" (Peter, father living in Highfields).

I do not want a school which is focused on language promotion. [...] It would be nice if they offered also something else from which my child will benefit as well" (Sandra, mother living in Highfields).

Thus, depending on the local educational infrastructure, the increasing inclination toward the careful selection of primary schools manifests differently in dissimilar neighbourhoods. In Highfields, the "matching process" (van Zanten, 2013) between the schools' profiles and the children's needs seems to be more strenuous. The parents' decision to "eat out" (Butler \& Robson, 2003) is thus driven by the perceived lack of acceptable local schools. Spatial proximity plays only a minor role. By contrast, as parents are surrounded by various schools offering the desired attention to their own children's needs, concerns about the appropriate promotion are just not necessary in Northville. The local school environment in Northville thus enables parents to pretend to draw on spatial proximity as the most important selection criterion. 

all parents. Thus, respondents in Highfields clearly reflect on the segregating effects of their school choice behaviour. Although they all decide on "putting the family first" (Jordan et al., 1994), they mention the dilemma they face between, on the one hand, being a "good citizen" and trying not to reinforce social and ethnic segregation between schools and, on the other hand, being a good parent by giving priority to their own child's future position by opting out of the local mixed school and avoiding the risks associated with the "wrong" mix (Raveaud \& van Zanten, 2007).

The changing parental perspective on the role of primary schools within the German education system is only partly reflected in the schools' strategies. Head teachers' responses to parental choice and to the abolishment of catchment areas differ significantly, as the next chapter illustrates.

\section{Schools' agency}

Despite the implementation of free school choice in NRW, children who attend the closest primary school are still prioritised, while other children can access the school only if places remain. Consequently, all head teachers in our case note that schools have limited opportunities to manipulate admission criteria and must prioritise the access of children living in their immediate environment. However, although officially denied, there still seems to be a small amount of room for organisational discretion, which is handled in completely different ways.

In Northville, the primary schools with a predominantly homogeneous (German) middleclass intake play down their promotional roles in advertising or canvassing. Trusting in the homogeneous (middle-class) intake of their local environment, they deny competition between schools. Only in some cases does a more strategic selection of pupils become visible, which mainly refers to the avoidance of more demanding children, e.g., refugees. Interestingly, their number varies significantly between the primary schools in the two neighbourhoods. This variation can be explained on the one hand by the spatial proximity of refugee homes to the primary schools in Highfields. On the other hand, primary schools seem to be able to refuse the admission of these children, as some interviews illustrate:

"We only have a small number of refugees in our school. From time to time, we are asked to admit these children, but our classes are quite full; this is just not possible. [...] A child who can hardly understand anything due to his language deficits sitting in our classes with all the individualised learning material - in my opinion, this would be overtaxing" (head teacher in Northville).

Moreover, channelling between nurseries and certain primary schools is well known and even politically supported if it affects the nurseries in direct spatial proximity to the primary schools. Nevertheless, in some cases, channelling seems to exceed the neighbourhood limits, as illustrated by the following quote from a mother living in Highfields but sending her children to a popular primary school in Northville:

"At first, I bothered: 'We live in Highfields; they [the primary school in Northville; author's note] won't accept us.' But then, one father in the nursery who has an older son told me that the children from our nursery always go there. That seems to be somehow reserved for them" (Ela, mother living in Highfields).

The primary schools in Highfields mostly deny the existence of competition between schools. However, there is substantial variability in the head teachers' responses and 
reasons. In particular, one head teacher is actively engaged in attracting (German) middle-class children to his school, a practice illustrated by other research studies (Jennings, 2010; Macguire et al., 1999; West et al., 2003). By actively advertising not only in the directly surrounding childcare centres - as is politically supported - but also in childcare centres that are outside the neighbourhood and therefore often have a different social and ethnic composition, he strategically tries to attract new social groups. In this case, the head teacher also denies the competition for pupils. However, in doing so, he refers only to the primary schools in Highfields that all have a very similar composition of pupils and not to the schools outside the neighbourhood that have a more "attractive" school composition.

"No, these [the other primary schools in Highfields; author's note] are not the schools whose children or parents I would like to have at my school. In no way. They are - the situation is similar like ours" (head teacher in Highfields).

As with the parents' narratives, the schools' admission criteria should not exclusively be studied from a class perspective; ethnicity, or language, are similarly important. The target group the mentioned head teacher tries to additionally attract consists of children with higher educated German (-speaking) parents:

"We are on the right way [to attract more German middle-class families; author's note]. Last week, we had some registrations from exactly this group. However, until now there are only few of them interested in our school since competition of schools is very high in Düsseldorf."

Interestingly, most head teachers in Highfields acted completely differently by vigorously refusing active choice. These differences were striking since all head teachers in Highfields wished for a socially and ethnically more heterogeneous composition. The less active head teachers embraced strategies often deployed by "ghetto schools", which "frequently adopt a position of retreat from the local market and focus mainly on helping children with learning problems and limiting discipline problems" (van Zanten, 2005, p. 163).

Apart from being inactive in attracting new middle-class parents to change the school's composition, in some cases, interested middle-class parents are even discouraged to apply. When asking for advice, other primary schools with a higher middle-class intake are recommended.

"There was also the school in Oak Street which we had a look at. Because I thought that it makes sense that our daughter spends time with other children, where it is more mixed. But the teachers told us that their attention for pupils with language deficiencies will be much higher than for children who learn quite quickly. [...] And yeah, somehow, I do feel influenced by that, which is quite normal, I guess. I do want my child to be supported and challenged. [...] So afterwards, the school was out of the question" (Julia, mother living in Northville).

"Then, teachers said: 'If you send your son to this school, he will be the only one who is different. You have to think about what you really gain from that experience"' (Mary, mother living in Northville).

Thus, the question arises why these schools preserve educational segregation rather than take part in the competitive educational market (Ball \& Maroy, 2009; van Zanten, 2005, 2009). To make sense of the contrasting positions in our sample, there might be different lines of explanation.

First, key figures in understanding the different logics of action are the schools' head teachers. According to van Zanten (2009), they tend to be the ones most concerned by the 
schools' position in the local marketplace. Their implication in the competition with other schools depends on several factors: their values and sensemaking processes, their belief in the possibility to improve the school's position in the local educational market, the degree to which they feel uncomfortable with the position of their school in the local hierarchy dimensions and national and local policies.

The head teachers' different values and sensemaking of the primary school choice process illustrate that "organizational actors both within and between organizations construct the demands of, and appropriate responses to, accountability systems differently" (Jennings, 2010, p. 229). Although they know about the importance of the schools' image or of achieving specific outcomes, these head teachers evaluate the schools' work against a parallel set of professional standards, such as the commitment to disadvantaged pupils.

"It is our pedagogical profile and the meaning behind: 'All children are welcome here"' (head teacher in Highfields).

Moreover, those head teachers also differ in their belief that they are able to improve the situation. They often rationalise their "inactiveness" based on their limited influence on the choice and admission process. After the abolishment of catchment areas, they consider parents the main players in this game of choice. Furthermore, their claim to their limited influence is closely related to frustration and scepticism about the schools' attractiveness - mainly due to the majority of ethnic others. This frustration and scepticism also seems to influence their staff:

"Maybe, but even if they [middle-class parents, author's note] came [to the school's open days; author's note], they might have the impression: 'It is quite nice, what they are doing here, but, to speak directly, there are too many foreigners, in my opinion.' So what can we really do in this case?" (social worker at primary school in Highfields).

"I could imagine that there are middle-class parents avoiding the primary schools in Highfields. For instance, if you come to a school party at our school; that is, yeah, there are only Muslim parents here. I do not know to what extent German parents would feel accepted and tolerated here. Here, we have other topics, such as halal food" (head teacher in Highfields).

31 However, the last quote indicates not only a lack of belief in their own capacity to attract other social groups - mainly German (-speaking) middle-class parents - but also their concern of how to integrate them. At this point, it becomes clear that apart from the distinctions between the schools, even within organisations, the logics of action do not always seem to be congruent. The head teachers in Highfields wish for a socially and ethnically more diverse composition, emphasising advantages such as a better learning environment or the existence of German language role models. Some of the schools' teachers and social workers, however, raise concerns about the matching of parents and schools - a process that has mainly been studied from the parents' perspective. In her research about Paris, Van Zanten (2013) illustrates that teachers who counsel parents to avoid the local schools act in line with the French conception of education-based meritocracy, which "encourages them to protect the educational careers of the brightest students" (p. 93). However, in our case, the teachers' behaviour seems to be guided less by meritocratic principles and more by their unease about the conflict between the expectations of especially middle-class parents and the schools' limited resources to meet these expectations. This leads to a situation in which schools prefer to focus on a less advantageous clientele and try to avoid, or at least try not to encourage, social mix. 
"Of course, I would like to improve the image of our school. [...] But I think it is pointless to run after them [middle-class parents; author's note] and to say: 'Hi, we do a lot in this school, and the staff is very committed.' This won't change the course. And the question is if it really is that reasonable and useful if the parents are not totally convinced. Then you have to work against them, and this will bring us only new potential for conflicts" (social worker at primary school in Highfields).

Thus, even if a head teacher believes in the school's capacity to improve the situation and believes in the value of social and ethnic mix, the implementation of his/her vision is strongly dependent on the staff's support.

"We are on our way to attracting more German middle-class parents. [...] I have been working at this school for two and a half years now. In the beginning, it was difficult, because there was a completely different atmosphere at this school. [...] Since primary schools are all very similar, the public image plays a decisive role [in attracting parents; author's note], for instance, how parents and their children are being welcomed. And this has improved a lot during the last two and a half years. [...] But this includes much effort of persuading, especially as regards the colleagues" (head teacher Highfields).

Second, apart from the key role of head teachers, the education system in Germany may be responsible for the inconsistencies in our sample. Being characterised by the (too) early division of educational tracks, the low permeability between tracks and high (social) selectivity, the primary school has a distinct role within the German education system. As illustrated, primary schools (still) contain the ideal of a local school, a school "for everyone". Strategically selecting more advantageous pupils who may achieve higher educational performance - which seems to take place in other European countries - may just be incompatible with that ideal.

"We are a socially and ethnically very mixed school. And anyway, the educational performances of children in a primary school are normally quite heterogeneous. This is based on the concept. After the fourth grade, we send our children to different educational tracks; that has to be like that. The reality can't be that we send $95 \%$ to the 'Gymnasium', since there do also exist other educational tracks" (head teacher in Highfields).

"We serve the families who live near here. Short legs, short distances. Children should be able to arrive at school quickly and not need to drive long ways" (head teacher in Highfields).

This ideal of the primary school as the "local school" also shapes the perception probably not the existence - of competition among schools. It serves as an "excuse" for retreating from the market and simply accepting the unequal distribution of children between different schools, and helps staff feel more comfortable with the position of the school in the local hierarchy:

"We do cooperate with the nurseries nearby but not with the other ones further away. We haven't strived for that, because I do not want to poach pupils from other schools. We do not compete with each other" (head teacher in Highfields).

\section{Conclusion}

The "positive competition" for which the NRW government strived when abolishing the school catchment areas resulted in quite different logics of action among primary schools. These different logics of action are based on different external and internal conditions, such as schools' intake and their position in the local hierarchy (van Zanten, 2005; Ball \& Maroy, 2009). Head teachers exercise their influential roles "on an uneven 
playing field inherited from the social geography of the city" (Herbert, 2000, p. 96). Thus, the implication of head teachers in the competition with other schools differs. Some schools seem to participate in this competition for pupils - although in a subtler and less explicit mode of market regulation than occurs in the UK, for instance. However, still trusting in the "short legs, short distances" slogans, most of the primary schools in Highfields focus on the pupils in their local environment and try to develop an educational concept that fits their specific clientele instead of proving that they are able to provide high-quality teaching that also targets middle-class children.

This form of profile-building mainly results in a focus on German language skills, which is reasonable and useful since it addresses their pupils' needs. Nevertheless, parents are highly influenced by these profiles. In particular, middle-class parents living in mixed neighbourhoods whose children already possess the necessary language skills and do not need any special teaching tend to "bridge out" of the neighbourhood (Savage et al., 2005). As a result, these parents - even with the support and encouragement of teachers and head teachers - choose schools mostly outside their neighbourhood that better fit their children's needs, and they consequently reinforce educational segregation.

Thus, the question is what role primary schools are supposed to play. The current policy of promoting primary schools' competition and simultaneously speaking in favour of the old ideal of the "local comprehensive" school seems hardly consistent. Moreover, although the matching between schools' offering and children's needs seems to be reasonable at first glance, it does not fit with primary schools' mandate of providing general education to all children, regardless of their cognitive abilities. Thus, by implementing school profiles, the initial claim of offering comparable education for all children might be given up.

Not all middle-class parents value the educational advancement of their children higher than the ideal of the "comprehensive" primary school next door. In those neighbourhoods, such as Northville, where the two aims can be combined, parents can afford the luxury of maintaining this ideal and can adjust their choice criteria to the pedagogical concepts of schools. In neighbourhoods where this is not the case, some parents repine about their school choice and reflect on the dilemma they face between their social ideals and the educational advancement of their own children. Ultimately, however, preferences lead to educational segregation within primary schools - a school type that was originally known for being "a school for all". Against the backdrop of the abolishment of primary school catchment areas and the (desired) establishment of school profiles, this may lead to different circuits of schooling and a division within the primary school "market". Mixed urban neighbourhoods seem to be good indicators of such a development since they demonstrate the fault lines between different social groups and (educational) organisations. 


\section{BIBLIOGRAPHY}

ANTIDISKRIMINIERUNGSSTELLE DES BUNDES (2015), Diskriminierung auf dem Wohnungsmarkt Strategien zum Nachweis rassistischer Benachteiligungen (Discrimination in the housing market Strategies to prove racist forms of disadvantage), Berlin, http://www.antidiskriminierungsstelle.de/ SharedDocs/Downloads/DE/publikationen/Expertisen/ Expertise_Wohnungsmarkt_20150615.pdf?__blob=publicationFile (accessed 8 February 2017). BALL S.J. (1994), Education Reform: A Critical and Post-Structural Approach, Buckingham, Open University Press.

BALL S.J., BOWE R. \& GEWIRTZ S. (1995), “Circuits of Schooling: A Sociological Exploration of Parental Choice of School in Social-Class Contexts", in HALSEY A.H., LAUDER H., BROWN P. \& STUART A (eds.), Education: Culture, Economy, and Society, Oxford, Oxford University Press, pp. 52-78.

BALL S.J., MAROY C. (2009), "School's logics of action as mediation and compromise between internal dynamics and external constraints and pressures", Compare: A Journal of Comparative and International Education, 39, 1, pp. 99-112.

BALL S.J., VINCENT C. (1998), “'I Heard It on the Grapevine': 'Hot' Knowledge and School Choice”, British Journal of Sociology of Education, 19, 3, pp. 377-400.

BOTERMAN W.R. (2013), “Dealing with Diversity: Middle-class Family Households and the Issue of 'Black' and 'White' Schools in Amsterdam", Urban Studies, 50, 6, pp. 1130-1147.

BUTLER T., ROBSON G. (2003), "Plotting the middle classes: gentrification and circuits of education in London", Housing Studies, 18, pp. 5-28.

BUTLER T., HAMNETT C. (2007), “The Geography of Education. Introduction”, Urban Studies, 44, 7, pp. 1161-1174.

BYRNE B. (2006), “In Search of a 'Good Mix': 'Race', Class, Gender and Practices of Mothering”, Sociology, 40, 6, pp. 1001-1017.

BYRNE B. (2009), "Not just class: towards an understanding of the whiteness of middle-class schooling choice", Ethnic and Racial Studies, 32, 3, pp. 424-441.

GILLBORN D., YOUDELL D. (2000), Rationing Education: Policy, Practice, Reform and Equity, Buckingham, Open University Press.

GROOS T. (2015), Gleich und gleich gesellt sich gern. Zu den sozialen Folgen freier Grundschulwahl, Gütersloh, Bertelsmann Stiftung.

HERBERT D. (2000), "School Choice in the Local Environment. Headteachers as gatekeepers on an uneven playing field", School Leadership \& Management, 20, 1, pp. 79-97.

HOLLINGWORTH S., WILLIAMS K. (2010), “Multicultural Mixing or Middle-class Reproduction? The White Middle Classes in London Comprehensive Schools", Space and Polity, 14, 1, pp. 47-64.

HOLLOWAY S.L. (1998), “Geographies of justice. Preschool-childcare provision and the conceptualisation of social justice", Environmental and Planning C, 16, 1, pp. 85-104. 
JENNINGS J.L. (2010), "School Choice or Schools' Choice? Managing in an Era of Accountability", Sociology of Education 83, 3, pp. 227-247.

JORDAN B., REEDLEY M., JAMES S. (1994), Putting the Family First: Identities, Decisions and Citizenship, London, University College London Press.

LANDTAG NORDRHEIN-WESTFALEN (2006), Drucksache 14/1572. Gesetzentwurf der Landesregierung. Zweites Gesetz zur Änderung des Schulgesetzes für das Land Nordrhein-Westfalen (2. Schulrechtsänderungsgesetz), Düsseldorf.

MACGUIRE M., BALL S.J., MACCRAE S. (1999), "Promotion, Persuasion, and Class-Taste: Marketing (in) the UK Post-Compulsory Sector”, British Journal of Sociology of Education, 20, 3, pp. 291-308.

NOREISCH K. (2007a), “Choice as Rule, Exception and Coincidence. Parents' Understandings of Catchment Areas in Berlin”, Urban Studies, 44, 7, pp. 1307-1328.

NOREISCH K. (2007b), "School catchment area evasion: the case of Berlin, Germany, Journal of Education Policy”, 22, 1, pp. 69-90.

RANGVID B.S. (2007), "Living and Learning Separately? Ethnic Segregation of School Children in Copenhagen”, Urban Studies, 44, 7, pp. 1329-1354.

RAVEAUD M., VAN ZANTEN A. (2007), “Choosing the local school: middle class parents' values and social and ethnic mix in London and Paris", Journal of Education Policy, 22, 1, pp. 107-124.

REAY D., CROZIER G. \& JAMES D. (2011), White Middle-class Identities and Urban Schooling, Basingstoke, Palgrave Macmillan.

RIEDEL A., SCHNEIDER K., SCHUCHART C. \& WEISHAUPT H. (2010), "School Choice in German Primary Schools: How Binding are School Districts?", Journal for Educational Research Online, 2, 1, pp. 94-120.

ROLLOCK N., VINCENT C., GILLBORN D., BALL S. (2012), “"Middle class by profession': Class status and identification amongst the Black middle classes”, Ethnicities, 13, 3, pp. 253-275.

SAVAGE M., BAGNALL G. \& LONGHURST B.J. (2005), Globalization and belonging, London, SAGE Publications Ltd.

VAN ACKEREN I. (2006), "Freie Wahl der Grundschule? Zur Aufhebung fester Schulbezirke und deren Folgen”, Die Deutsche Schule, 98, 3, pp. 301-310.

VAN ZANTEN A. (2005), "New Modes of Reproducing Social Inequality in Education: the changing role of parents, teachers, schools and educational policies", European Educational Research Journal, 4, 3, pp. 155-169.

VAN ZANTEN A. (2009), “Competitive arenas and schools' logics of action: a European comparison", Compare: A Journal of Comparative and International Education, 39, 1, pp. 85-98.

VAN ZANTEN A. (2013), “A Good Match. Appraising Worth and Estimating Quality in School Choice”, in MUSSELIN C., BECKERT J. (eds.), Constructing Quality. The classification of goods in markets, Oxford, Oxford University Press, pp. 77-100.

VINCENT C., BALL S.J. (2001), “A Market in Love? Choosing Pre-school Childcare”, British Educational Journal, 27, 5, pp. 633-651.

VINCENT C., ROLLOCK N., BALL S. \& GILLBORN D. (2012), "Being strategic, being watchful, being determined: Black middle-class parents and schooling”, British Journal of Sociology of Education, 33, 3, pp. 337-354. 
VOWDEN K.J. (2012), "Safety in numbers? Middle-class parents and social mix in London primary schools”, Journal of Education Policy, 27, 6, pp. 731-745.

WEISHAUPT H., SCHNEIDER K., SCHUCHART C. \& RIEDEL A. (2012), “The effect of free primary school choice on ethnic groups: Evidence from a policy reform", European Journal of Political Economy, 28, 1, pp. 430-444.

WEST A., HIND A. (2003), "Secondary School Admissions in England: Exploring the Extent of Overt and Covert Selection, Working Paper, Research and Information on State Education Trust, London, England.

WEST A., HIND A. \& PENNELL H (2003), “Secondary Schools in London: Admissions Criteria and Cream Skimming”, Working Paper, Research and Information on State Education Trust, London, England.

\section{NOTES}

1. Primary schools in most federal states in Germany contain the first four years of schooling between the ages of six and ten.

2. In Germany, national league tables in which (primary) schools are - visible for everyone evaluated and ranked, as in the UK are neither existent nor politically wanted. However, the abolishment of catchment areas in NRW can be understood as the first step toward more competition between primary schools.

3. Research in Düsseldorf was carried out with Sabine Beißwenger, Heike Hanhörster and Sabine Weck, all with ILS - Research Institute for Regional and Urban Development, Dortmund.

4. In line with our definition, which is based primarily on educational background, 28 of the 32 interviewees can be defined as middle class: 24 of them have a university degree, and four have a university entrance qualification in combination with middle-class professional occupations. The remaining four interviewees can be defined as working class (e.g., no school-leaving qualification or no university entrance qualification).

5. In addition, there is a mixed school type, the Gesamtschule, where a higher entrance qualification can also be achieved.

6. Moreover, the appreciation for their children having school peers from all ethnic minorities refers to children of middle-class parents; parents seem to be far less comfortable if this is not the case.

\section{ABSTRACTS}

Within the German education system, primary schools underlie the ideal of a comprehensive and local school. However, this perception is changing: Increasingly, parents are carefully selecting the "right" primary schools for their children, and in some federal states, school catchment areas have been abolished to encourage "responsible competition" among schools. Whereas most studies on school choice focus on parents' educational strategies, this paper analyses the role of primary schools within this choice process. It notes the divergent ways in which primary schools 
- depending on the social geography of the city and their position within the educational market - respond to these policy changes and the changing parental demands confronting them.

Im deutschen Schulsystem unterliegt die Grundschule dem Ideal einer Schule, die von allen Kindern in der unmittelbaren Umgebung besucht wird. Diese Wahrnehmung scheint sich jedoch zu verändern - zum einen aus der Sicht der Eltern, die zunehmend strategisch die "richtige" Grundschule für ihre Kinder wählen, zum anderen aus einer politischen Perspektive, die zur Förderung eines "verantwortlichen Wettbewerbs" die Grundschuleinzugsbereiche aufgelöst hat. Während die Mehrheit wissenschaftlicher Studien die elterlichen Bildungsstrategien untersucht, richtet dieser Artikel den Blick auf die Rolle der Grundschulen innerhalb dieses Wahlprozesses. Der Artikel verweist auf die - je nach sozialräumlichen Strukturen und ihrer Position im lokalen "Bildungsmarkt" - höchst unterschiedlichen Antworten der Grundschulen auf die veränderten politischen Rahmenbedingungen sowie die zunehmenden elterlichen Ansprüche, mit denen sie konfrontiert sind.

INDEX

Keywords: school choice, school competition, parental educational strategies, Germany Schlüsselwörter. Schulwahl, Schulwettbewerb, elterliche Bildungsstrategien, Deutschland

\section{AUTHOR}

\section{ISABEL RAMOS LOBATO}

ILS - Research Institute for Regional and Urban Development, isabel.ramos-lobato@ilsforschung.de 